\title{
Research on the Competitive Power of Famous Sports Brands in China
}

\author{
Lihong Dong \\ Shanghai Second Polytechnic University \\ Pudong New Area, Shanghai, China \\ dlh20082001316@sina.com
}

\author{
Qun Cong \\ Shanghai Second Polytechnic University \\ Pudong New Area, Shanghai, China \\ congqun@sspu.edu.cn
}

\begin{abstract}
Through literature, field investigation, induction and mathematical statistics research methods, from the current complex economic situation at home and abroad.Discussed "the gain and loss "of the developing pattern of famous sportswear industry in china", Pointed out that after the brief Olympic effect in 2008, the development model of famous sportswear in China has already encountered unprecedented challenges at present, domestic market presents homogeneity and vicious competition characteristics, the foreign market appeared the phenomenon of "short board".This article considers, in order to upgrade the living space of famous sportswear enterprises and transnational sports brand jungle in china, The key link lies in the innovative construction of its own brand competitiveness.
\end{abstract}

Keywords—Famous sports brand, Competitiveness

\section{INTRODUCTION}

Since China's reform and opening to the outside world, after more than 30 years of development, the sportswear industry in China is transforming into a "metamorphosis". In the initial stage of reform and opening up, profit from the shortage of sportswear in the market, sportswear production has taken a "speed and efficiency" development path characterized by large-scale expansion before "95". Moreover, this development model peaked at the 2008 olympics. But since then, with the complex economic situation at home and abroad change, throughout the country, the development of the sport apparel industry has begun to experience unprecedented challenges.The operating environment of sportswear enterprises is becoming more and more difficult. At present, The domestic market share of sportswear is being gradually eroded, a large number of small and medium-sized sports apparel enterprises even appeared "Closures". Therefor, for this the author makes a further investigation of embarrassment, after view and study the internal and external factors, compared with the mature sportswear brands of international transnational corporations, even the more well-known sportswear brand enterprises in our country, their brand competitiveness still presents a "short board" phenomenon, it makes it impossible to compete with big brands such as Nike and Adidas. In this grim situation, Obvious, it is difficult for China's famous sports brand clothing industry to develop its traditional "speed and efficiency" type. Therefore, how to promote the survival space of jungle competition between our well-known sports brand enterprises and transnational sports brands, let them succeed in the transformation, urgent need to solve. Based on this, the author tries to start with the increasingly complicated economic situation, Try hard to enhance the competitiveness of our own brands, and comprehensively restore and construct the competitive strategies of famous sports brands in china, the purpose is to effectively promote the sustainable development of famous sports brand enterprises in china.

\section{The DEFINITION OF WELL-KNOWN SPORTS BRANDS}

Generally speaking, starting from the study of the intrinsic attributes of sports brands, the definition of sports brands is first divided according to $\mathrm{t}$ the level of brand behavior. Through the ranking of internationally renowned sports brands, the top ten brands of international sports brands are sorted in turn: The United States Nike (Nike), Germany's Adidas (Adidas), Britain's Reebok (Reebok), Germany's Puma (PUMA), Italy FILA (FILA), Japanese Mizuno Shannon (Mizuno), Britain's UMBRO (UMBRO), Italy Kappa (KAPPA), Diadora (DIADORA) and Lotto (LOTTO). [1]The sort of sports brand shows, the top ten well-known sports brands have not yet been made in china. Through the domestic sports brand research findings, the more well-known sports brands in the country include: Lining (LI-NING), Anta (ANTA), XTEP (XTEP). 361 Degrees (361 degrees), PEAK (PEAK), Binary (Doublestar), Voight (VOIT), Erke (ERKE), Guirenniao, Sai Qi (SAIQI), Xdlong, De Erhui, Kingclean (JINAK) and Jordan (QiaoDan Chinese).

\section{The COMPETITIVE SituAtion OF WELL-KNOWN SPORTS BRANDS IN CHINA}

\section{A. Brand management model behind, homogenization, vicious competition serious}

In the field of brand research, according to Michael Potter's theory of competitive strategy, The enterprise wants to gain the competitive advantage, three basic strategies need to be developed:Unconventional and innovative, total cost leadership and target concentration strategy. And when the latter strategy fuses the first two strategies,it naturally presents itself as a target focused cost leadership strategy and an innovative strategy of targeting. However, in reality, search and study the well-known sports brand management model 
found in china, In the process of rapid expansion and extensive development, the operation of most well-known sports brand enterprises emphasizes on the development model of staking and quantity winning. This leads to the backwardness of the sports brand management model, Make the development model of domestic sports brand collective appeared two "sequela". On the one hand, many leaders of sportswear enterprises suffer from "myopia", embodied in the serious lack of awareness of innovation, brand positioning vague, and do not have the ability to market segmentation, bottlenecks in the market development, mining and other aspects of demand; On the other hand, brand management is lagging behind, the brand lacks design power and cultural identity.This directly led to today's domestic sports brand homogenization, vicious competition pattern.And the homogenization of vicious competition first reflected in the industry imitation, product similarity, and so on. Secondly, the chain stores tend to be more competitive. Such as Lining, Anta, XTEP, 361, PEAK and other well-known sports brands are using a large number of open chain form. Thus it can be seen,in this homogeneous and hyper competitive environment, the vicious competition of domestic sports brand management, Instead, it will bring market opportunities for international famous sports brands such as Nike and Adidas, and thus further widen the gap between domestic and international sports brand development.

\section{B. The market struggle faces two domestic and international markets double suppression}

Compared with the development of world famous sports brands, the development of sports brand industry started relatively late in our country. With the great success of reform and opening to the outside world, since the beginning of 1980s to the 2008 Beijing Olympic Games, China's sports brand industry is a spiral upward trend, the cycle of development is the entire domestic sports brand development of the golden age. With the help of the reform and opening up and the Olympic Games, a few domestic sportswear enterprises have been developing vigorously, and they have begun to attach importance to the creation of their own brands. At present, there are dozens of well-known sports brands in our country. According to the statistics of China's famous sports brands in 2010, the top ten sports brands in China include: 1) Lining,2) Anta, 3) PEAK , 4) XTEP, 5) 361 ,6) Erke, 7) Qingdao Double Star, 8) Jordan ,9) Conway ,10) Deerway.These ten sports brands occupy a higher share in the domestic market, and occupy the majority of China's low-end sports apparel market. But in the domestic high-end sports clothing market, because of the brand technical content and the influence is weaker, the domestic sports brand's market share is obviously lower than the international brand. Thus, in the domestic sports brand market share, the domestic and international sports brand market share presents the polarization rule. That is, domestic well-known sports brands have dominated the low-end sportswear market for a long time through low-cost strategies, and foreign well-known sports brands have a high premium to guide high-end sports apparel market. However, after a short Olympic effect, the balance of the two poles appeared a big market inflection point.Embodied in two aspects: first, the foreign well-known sports brand marketing strategy appeared a big strategic shift, and began to brand penetration to the domestic two or three - line sportswear market.Such as Nike, Adidas and other international sports brands began to adopt low-cost strategy to enter the domestic city two or three line of low-end sports apparel market. Two, the famous domestic sports apparel brand strategy presents a great adjustment, which leads to a serious migration of brand strategy, in the brand competitiveness is relatively immature, the brand marketing will be adjusted to "high-end" route. Such as Lining Group in 2008 after the Olympic Games, relying on the Olympic Games effect, the high-profile entry into the highend market at home and abroad sports brand clothing, many times to improve the price of Lining's products. In view of this, the two different brand strategy contrast has already brought the huge impact to the well-known sports brand. According to statistics, in the first half of 2012, Lining Group closed 1200 inefficient stores on the basis of the opening of only 248 shops. The proportion of closed stores was as high as $15 \%$.By June 30, 2012, the number of shops in Lining's regular stores, flagship stores, factory stores and discount stores was 7303, down 952 from the end of 2011. At the same time, Lining Group released in March 2013 annual report, the company in 2012 the huge loss of nearly 2 billion yuan. [2]PEAK sports 2012 report also shows that as of September 30, 2012, its authorized operating retail outlets in China was 6739, compared with the end of 2011 to reduce 1067. [3]In addition, other statistics are also shown, a number of well-known sportswear brands have also shown signs of reduced retail outlets and declining profitability.This fully shows that the current domestic sports brand enterprise's traditional business model has been greatly challenged, and have to face the dual suppression of domestic and foreign sports brand competition.

\section{The cost of competition is fierce, low cost advantages gradually disappear}

In recent years, China's well-known sportswear enterprises have appeared industry orders decline, and the number of stores reduced, On the one hand, the demand for sportswear is shrinking in the domestic and international markets; on the other hand, it comes from the decline of the traditional manufacturing model of sportswear enterprises. The decline, in short, is the loss of competitive costs and the disappearance of low-cost advantages. For decades, the famous sportswear enterprises in China have continued the development of "speed and efficiency". This development model depends on the lower cost advantage at that time. Such as energy and resource advantages, especially relying on the advantages of low cost of manpower,the well-known sports clothing enterprises in China occupy most of the domestic medium and low-end market, and achieved considerable returns to scale. However, The 2008 Olympic Games made a brief push for famous sportswear enterprises in china, become a well-known garment enterprises development boundaries. Nowadays, with the rapid development of China's economy, the demand for energy and resources continues to rise, leading to the trend of resource cost rising in sports apparel industry, In other words, natural resources that are already cheap and even free are no longer available, the cost of manpower has changed radically, as China gradually approaching the "Lewis inflection point" after. Therefore, it is easy to understand the deterioration of 
the operating environment of the well-known sportswear enterprises from the low cost advantage. And what is more worrying is.., Because of the blind optimism about the effect before and after The 2008 Olympic games, many well-known sportswear enterprises in China have increased their scale expansion, and as a result, the business environment has deteriorated.This kind of enterprise has appeared high inventory and low profit status, which in turn led to the decline of brand competitiveness.

\section{OUR FAMOUS SPORTSWEAR ENTERPRISES ENHANCE BRAND COMPETITIVENESS STRATEGY}

\section{A. Provide industrial policy support, the formation of aircraft carrier famous sports brand enterprise group}

In the complicated new economic situation, compared with the mature international well-known sports brand operating strategy, most of the well-known sportswear enterprises in China are losing their cost competition and the gradual loss of low-cost resource advantages.In competition with foreign brand competition, domestic enterprises will be unable to resist the impact of international brand enterprises. Therefore, the government should actively guide the development of well-known sportswear industry in China, and increase the support for the sports apparel industry. On the one hand, we should give full play to the role of market rules and eliminate the inferior and retain good ones, In this process, the government should tilt the preferential policies more towards the innovative construction of famous sports clothing brands rather than the "one size fits all" model; On the other hand, only "big and strong" sportswear enterprises can compete for international well-known sports brand market share, the government should take the top three domestic well-known sports clothing enterprises as the core to build Chinese sports clothing brand "aircraft carrier", rather than believe in the law of sports clothing market, "God's hand", let the small sportswear enterprises to resist the large international sportswear enterprises. If the Chinese sports clothing industry to implement industry to maximize the transnational group strategy, will greatly enhance China's well-known sports clothing enterprise's competitiveness, is bound to force international brands like Nike, MIZUNO and other large sports clothing enterprises to make more market space.

\section{B. Enhance the independent innovation ability of sports clothing products, and strive for the construction of brand standards}

Philip Kotler defines products like this: anything that can be provided to the market to attract attention, access, use, or expense to satisfy a certain desire or need.The product is divided into three levels: core products, tangible products and extended products. [4]There is no doubt about it, the quality of the three types of products is related to the vitality of the sports apparel enterprises, Only by firmly grasp the quality of sports clothing products, it is possible to enhance the independent innovation ability of sports apparel products. This is because product quality is the life of sportswear enterprises, the basis of independent innovation of sportswear, and the fundamental guarantee for the competitiveness of sportswear enterprises. On this premise, through the full independent innovation ability construction, the brand will naturally become the carrier of the quality and reputation of sportswear enterprises, and will be more and more market awareness and share more market share.Besides, in the focus on seizing the commanding heights of the market, in addition to relying on independent innovation capacity-building, but also committed to brand standard construction, standards are the commanding heights of independent innovation, in the entire sports apparel brand operations. If a well-known sportswear enterprises have mastered the right to speak industry standards, it will control the initiative in the market competition. Therefore, in order to make and strengthen the brand competitiveness of well-known sportswear enterprises,it should strive to make breakthroughs in the construction of industry standards.

\section{Pay attention to the promotion of human capital}

In any production element of an enterprise, human capital has always been an important factor affecting the promotion of enterprise competitiveness.Domestic well-known sportswear enterprises are no exception, in the process of building famous brands and promoting brand competitiveness, the introduction of talents, attracting talents, using talents and how to retain talents will be an important guarantee for the sportswear enterprises to maintain their brand competitiveness. Therefore, paying attention to the promotion of human capital is the most important thing in the development of sportswear brand enterprises. On specific measures, sportswear enterprises need to develop effective talent mechanism, and this kind of talent mechanism can be divided into two parts. In the introduction of talent mechanism on the outside, increase the absorption of outstanding management personnel, technical personnel to the enterprise.At the same time, this part of the personnel to establish a relatively perfect training, promotion and salary system, and enhance their loyalty to the enterprise, and then make themselves into a part of the enterprise; In the internal personnel training mechanism, it should establish internal staff common values, provide incentives and program diversification, training of internal staff motivation, so that each employee to fully reflect their own values, play to their creativity.

\section{SUMMARY}

The competitive situation of famous sports brands in our country has:brand management mode behind, homogenization, vicious competition serious; The market struggle faces two domestic and international markets double suppression; The cost of competition is fierce, low cost advantages gradually disappear.

Our famous sportswear enterprises enhance brand competitiveness strategy: Provide industrial policy support, the formation of aircraft carrier famous sports brand enterprise group ; sports Enhance the independent innovation ability of sports clothing products, and strive for the construction of brand standards;Pay attention to the promotion of human capital. 


\section{ACKNOWLEDGMENT}

In the whole paper writing, the author of this thesis is given a full range of instruction from the authoritative scholars in this field, and deeply grateful to them for their selfless help.

\section{REFERENCES}

[1] Medical aircraft. Sports brand.http://baike.baidu.com[ EQ]

[2] Eastern net. Domestic sports brands suffered winter depth adjustment facing transformation pressure.http:// finance.qq.com [ EQ]

[3] Workers daily. Domestic sports brand how to help themselves in winter. http:// news.xinhuanet.com/comments [ EQ]

[4] Philip, Kotler, Mei Qinghao translation “Marketing Management” Asian edition, Second Edition, [M]., Beijing: Renmin University of China press, 2001 